\title{
PERBEDAAN HASIL BELAJAR SISWA ANTARA YANG DIAJAR DENGAN MENGGUNAKAN MODEL PEMBELAJARAN KOOPERATIF TIPE THINK PAIR SHARE (TPS) DENGAN YANG DIAJAR DENGAN MODEL PEMBELAJARAN LANGSUNGPADA MATERI POKOK FENOMENA ANTROPOSFER DAN ASPEK KEPENDUDUKAN
}

\author{
Wa Syarni Baso ${ }^{1}$ \\ ${ }^{1}$ Program Studi Pendidikan Geografi, Universitas Halu Oleo, Kendari.
}

Abstract: This study aims to: 1) To know the significant difference between mean value of experiment class pree-test with pree-test control class. 2) To know the average value of the experiment class post-test is significantly better than the average value of post-test control class. 3) To find out the average value of experiment class gain is better than the average value of control class gain.Based on data analysis, it is concluded that: 1) There is a difference between the average of pree-test of the experimental class students with the average of pree-test of the control class students but not significant. This is indicated by the value of ttabe $1<\mathrm{t}$ count $(1.142<2.001)$. at $\alpha=0.05$. 2) There is a difference between the mean post-test of the experimental class students with the mean post-test of the control class students but not significant, which is shown by the $t$ count $<$ ttable $(1.86$ $<2.001)$ at $\alpha=0.05$. 3) There is a difference between the N-gain of the experimental class students and the $\mathrm{N}$-gain of the control class students but not significantly indicated by the t count $<$ ttable $(1.67<2.001)$. at $\alpha=0.05$.

\section{Kata Kunci: Model Pembelajaran,Think Pair Share (TPS), Pembelajaran Langsung, dan Hasil Belajar}

\section{PENDAHULUAN}

Dalam proses pembelajaran di
kelas, tidak terkecuali dalam
pembelajaran geografi harus terus
diupayakan peningkatan-peningkatan ke
arah berkembangnya kemampuan siswa.
Peserta didik akan menghadapi
tantangan berat pada masa yang akan
datang karena kehidupan masyarakat
global selalu mengalami perubahan
setiap saat. Model pembelajaran yang
tidak memberikan kesempatan kepada
siswa untuk aktif dan kreatif harus
segera ditinggalkan dan diganti dengan
pendekatan-pendekatan atau metode-
metode pembelajaran yang berpusat
kepada siswa.Untuk itu, konsep
pembelajaran saat ini harus berubah dari

guru mengajar menjadi siswa belajar.Siswa tidak lagi diposisikan sebagai objek belajar, melainkan siswa diposisikan sebagai subjek yang belajar sesuai bakat, minat, dan kemampuan yang dimilikinya.

Berdasarkan hasil pra penelitian di SMA Negeri 8 Kendari menemukan bahwa nilai rata-rata yang dicapai oleh siswa kelas XI pada ulangan harian mata pelajaran geografi yaitu hanya mencapai 61,35(Dokumen SMA Negeri 8 Kendari). Berdasarkan pengamatan peneliti pada saat observasi awal di sekolah, sebagian guru dalam proses belajar mengajar masih menggunakan yang berbasis pada guru. siswa hanya mendengarkan dan tidak pasif selama proses belajar mengajar berlangsung.

Wa Syarni Baso 
Hal tersebut mengakibatkan rendahnya minat dan motivasi belajar siswa, sehingga hasil belajar yang diperoleh siswa tidak mencapai kriteria ketuntasan minimal (KKM) yang ditetapkan sekolah.

Melihat kenyataan tersebut di atas, maka peneliti tertarik untuk mengadakan penelitian mengenai hasil belajar geografii pada siswa SMA Negeri 8 Kendari dengan mengambil judul "Perbedaan hasil belajar siswa antara yang diajar dengan menggunakan model pembelajaran kooperatif tipe Think Pair Share (TPS) dengan yang diajar dengan model pembelajaran Langsung (Studi eksperimen pada kelas XI IPS di SMA Negeri 8Kendari)".

Penelitian ini bertujuan: 1) Untuk mengetahui perbedaan signifikan antara nilai rata-rata pree-test kelas eksperimen dengan pree-test kelas kontrol. 2) Untuk mengetahui nilai rata-rata post-test kelas eksperimen lebih baik secara signifikan dari pada nilai rata-rata post-test kelas kontrol. 3) Untuk mengetahui nilai ratarata gain kelas eksperimen lebih baik secara signifikan dari pada nilai rata-rata gain kelas kontrol.

Model pembelajaran diartikan suatu kerangka konseptual dari kegiatan pembelajaran tersebut.Menurut Joyce dalam Trianto (2007), model pembelajaran adalah suatu perencanaan atau suatu pola yang digunakan sebagai pedoman dalam merencanakan pembelajaran di kelas atau pembelajran dalam tutorial dan untuk menetukan perangkat-perangkat pembelajaran termasuk didalamnya buku-buku, film, komputer, kurikulum, dan lain-lain.

Salah satu model pembelajaran yang banyak digunakan oleh guru adalah model pembelajaran kooperatif yaitu suatu model pembelajaran dimana sistem belajar dan bekerja dalam kelompok-kelompok kecil yang berjumlah 4-6 orang secara kolaboratif sehingga dapat merangsang siswa lebih bergairah dalam belajar.Slavin (2008: 4) menjelaskan bahwa pembelajaran koperatif merujuk pada berbagai metode pembelajaran dimana peserta didik bekerja dalam kelompok-kelompok kecil untuk saling membantu satu sama lainnya dalam memperlajari materi pelajaran. Dalam kelas kooperatif, para peserta didik diharapkan dapat saling memmbantu, saling mendiskusikan dan beragumentasi, untuk mengasah pengetahuan yang mereka kuasai saat itu dan menutup kesenjangan dalam pemahaman masing-masing.Salah satu model pembelajaran kooperatif yaitu model pembelajaran kooperatif tipe Think Pair Share (TPS).

Pembelajaran model kooperatif tipe Think Pair Share dapat mengembangkan potensi yangdimiliki siswa secara aktif, karena siswa dibagi kedalam kelompok yang beranggotakan 2 orang.Dalam Anita (2002: 45) dipaparkan keuntungankelompok yang beranggotakan dua orang yaitu:meningkatkan partisipasi siswa, lebih banyak untuk kontribusi masingmasing anggota kelompok, interaksi lebih muda, cocok untuk tugas sederhana, lebih mudah dan cepat membentuknya. Ibrahim

(2000: mengemukakan langkah-langkah pelaksanaan strategi Think-Pair-Share yaitu. 1) Thinking (berpikir). Pada tahap ini, guru mengajukan pertanyaan atau suatu masalah yang berhubungan dengan pelajaran, kemudian siswa 
diminta untuk memikirkan pertanyaan atau masalah tersebut secara mandiri untuk beberapa saat. 2). Pairing (berpasangan). Pada tahap ini, siswa berpasangan dengan siswa lain, kemudian mendiskusikan jawaban yang telah mereka pikirkan pada tahap pertama. Interaksi ini diharapkan dapat saling berbagi jawaban sehingga diperoleh satu jawaban sebagai hasil diskusi berpasangan tersebut. 3) Sharing (berbagi). Pada tahap ini, guru meminta kepada pasangan untuk berbagi dengan seluruh kelas tentang apa yang telah mereka diskusikan. Ini efektif dilakukan dengan cara bergiliran pasangan demi pasangan dan dilanjutkan sampai sekitar seperempat dari seluruh jumlah pasangan dapat diberi kesempatan untuk melaporkan hasil diskusi mereka secara bergiliran.

Adapun model pembelajaran langsung menurut Sofan Amri \& Iif Khoiru Ahmadi, (2010:39) bahwa Model Pembelajaran Langsung dirancang khusus untuk mengembangkan belajar siswa tentang pengetahuan prosedural dan pengetahuan deklaratif yang terstruktur dengan baik dan dapat dipelajari selangkah demi selangkah. Yang dimaksud dengan pengetahuan deklaratif (dapat diungkapkan dengan katakata) adalah pengetahuan tentang sesuatu.sedangkan pengetahuan prosedural adalah pengetahuan tentang bagaimana melakukan sesuatu. Arends dalam Sugiarto (2008:49), mengatakan: "Model pembelajaran langsung dikembangkan secara khusus untuk meningkatkan proses pembelajaran para siswa terutama dalam hal memahami sesuatu (pengetahuan) dan menjelaskannya secara utuh sesuai pengetahuan procedural dan pengetahuan deklaratif yang diajarkan secara bertahap".

\section{METODE PENELITIAN}

Penelitian ini dilaksanakan pada bulan September tahun 2016 semester I Tahun ajaran 2016/2017 di SMA Negeri 8 Kendari.Populasi dalam penelitian ini adalah seluruh siswa kelas XI IPS pada SMA Negeri 8 Kendari yang terdaftar pada tahun pelajaran 2016/2017. Penentuan sampel berdasarkan pertimbangan tertentu yaitu kelas yang menjadi objek penelitian memiliki kemampuan rata-rata siswa yang hampir sama. Berdasarkan teknik pengambilan sampel ini, maka peneliti menetukan kelas XI IPS ${ }_{1}$ sebagai kelas eksperimendan XI IPS 2 sebagai kelas kontrol pada sampel penelitian.

Desain yang digunakan dalam penelitian ini adalah eksperimen semu (quasi experimental design) dengan rancangan nonequivalent controlgroup design. Tujuan penelitian eksperimen semu adalah untuk memperoleh informasi yang merupakan perkiraan bagi informasi yang dapat diperoleh dengan eksperimen yang sebenarnya dalam keadaan yang tidak memungkinkan untuk mengontrol dan/atau memanipulasikan semua variable yang relevan Suryabrata (2012: 92)..Data yang dikumpulkan dalam penelitian melalui hasil tes belajar siswa pree-test dan post-test pada kelas eksperimen dan kelas kontrol. Teknik analisis data yang digunakan dalam penelitian ini adalah statistik deskriptif dan statistik inferensial berupa uji normalitas, uji homogenitas, uji N-Gain dan uji t. 
Tabel 2.1. Design penelitian

\begin{tabular}{cccc}
\hline Kelas & Pree-test & Perlakuan & Post-test \\
\hline Eksperimen & $\mathrm{O}_{1}$ & $\mathrm{X}_{\mathrm{a}}$ & $\mathrm{O}_{2}$ \\
\hline Kontrol & $\mathrm{O}_{1}$ & $\mathrm{X}_{\mathrm{b}}$ & $\mathrm{O}_{2}$ \\
\hline
\end{tabular}

Sumber:Tuckman(1978:131-132)

HASIL PENELITIAN DAN pada siswa di kelas kontrol. Untuk kelas PEMBAHASAN

eksperimen,proses pengambilan data hasil belajar siswa, menggunaan model

\section{Deskripsi Hasil Penelitian}

Dalam penelitian ini dideskripsikan data tentang pree-test dan post-test hasil belajar siswa, baik siswa kelas eksperimen maupun siswa kelas kontrol.Pada penelitian ini data hasil penelitian diperoleh melalui pemberian hasil tes (hasil belajar) siswa, baik itu pada siswa kelas eksperimen maupun

Tabel 3.1Nilai rata-rata pree-test dan post-test kelas eksperimen dan kelas kontrol

\begin{tabular}{ccccc}
\hline \multirow{2}{*}{ Nilai } & \multicolumn{2}{c}{ Kelas Eksperimen } & \multicolumn{2}{c}{ Kelas Kontrol } \\
\cline { 2 - 5 } & Pree-test & Post-test & Pree-test & Post-test \\
\hline Rata-rata & 31,99 & 73,33 & 28,21 & 67,77 \\
\hline Sta. Deviasi & 13,72 & 10,05 & 12,09 & 10,66 \\
\hline Maksimum & 53,33 & 93,33 & 53,33 & 86,67 \\
\hline Minimum & 13,33 & 60 & 13,33 & 53,33 \\
\hline
\end{tabular}

Sumber: Data Diolah (2017)

Gambaran peningkatan hasil belajar Geografi siswa antara kelas kontrol dan

eksperimen dapat dilihat pada gambar 1 berikut,

Gambar 3.1 Grafik Peningkatan Hasil Belajar Geografi Siswa Kelas Kontrol dan Kelas Eksperimen

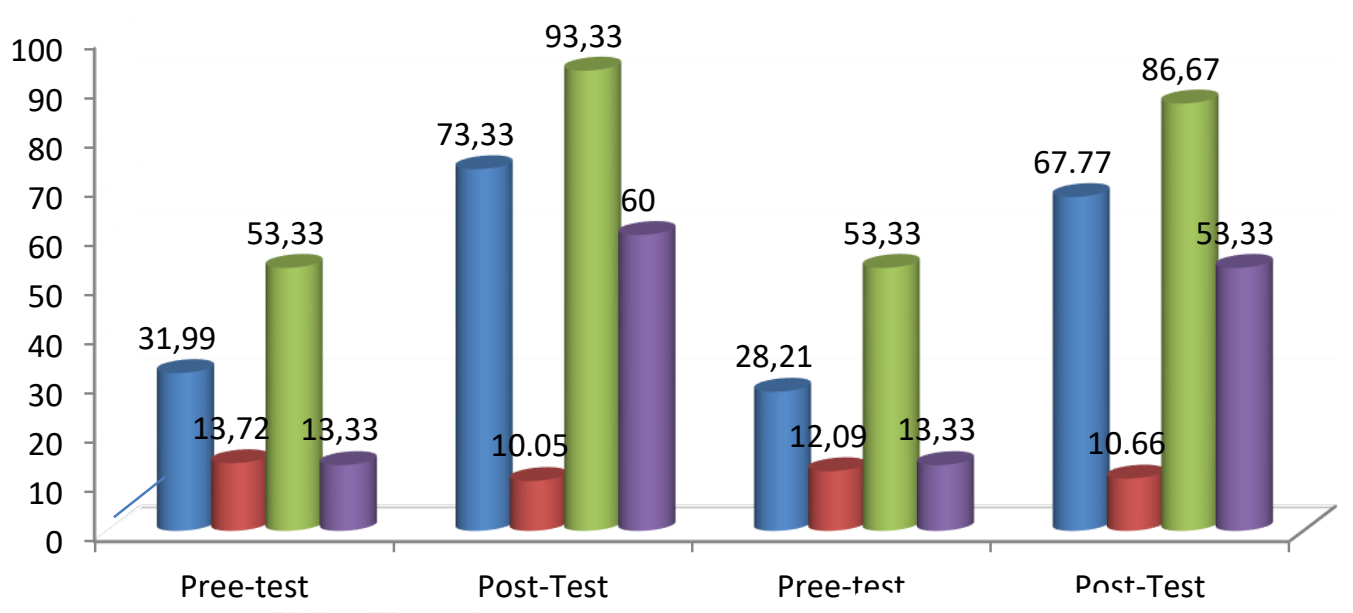

Kelas Eksperimen

Kelas Kontrol

Rata-rata $\square$ Sta. Deviasi Maks. Min. 
Gambaran hasil belajar siswa pada post-testyang terlihat gambar 1 menunjukan bahwa terjadi peningkatan signifikan hasil belajar siswa pada kelas kontrol maupun kelas eksperimen. Nilai rata-rata hasil belajar siswa kelas eksperimen pada post-tes sebesar 73,33, nilai maksimal 93,33, nilai minimum 60 , dengan 11 orang siswa kategori hasil belajar cukup, 13 orang siswa kategori hasil belajar baik, 6 orang siswa kategori hasil belajar sangat baik, dan standar deviasi 10,05. Sedangkan nilai rata-rata hasil belajar siswa kelas kontrol pada post-test sebesar 67,77, nilai maksimal 86,67 , nilai minimum 53,33, dengan 7 orang siswa kategori hasil belajar kurang, 8 orang kategori cukup, 13 orang siswa kategori baik, 2 orang siswa kategori sangat baik dan standar deviasi 10,66 .

\section{Hasil Analisis Statistik Inferensial}

\section{a. Pengujian Normalitas Data}

Uji normalitas dilakukan untuk melihat sebaran data tersebut normal atau tidak. Berdasarkan uji normalitas menggunakan Kolmogorov Smirnov datapree-test dan post-test kelas eksperimen dan kelas kontrol yang diolah menggunakan Ms. Excel 2007.Hasil uji normalitas pree-test dan Post-test kedua kelompok sampel penelitian ditunjukkan pada tabel berikut,

Tabel 3.2 Hasil Uji Normalitas Pree-test dan Post-test Kelas Kontrol

\begin{tabular}{cccc}
\hline Kelas Kontrol & $\chi^{2}$ hit & $\chi_{\text {tab }}^{2}$ & Keterangan \\
\hline Pree-test & 7.369 & 7.81 & Terdistribusi normal \\
\hline Post-test & 6.654 & 7.81 & Terdistribusi normal \\
\hline & \multicolumn{3}{c}{ Pada $\alpha=0.05$} \\
\hline
\end{tabular}

Sumber: Data Diolah (2017)

Tabel 4. Hasil Uji Normalitas Pree-test dan Post-test Kelas Kontrol

\begin{tabular}{cccc}
\hline Kelas Kontrol & $\chi^{2}{ }_{\text {hit }}$ & $\chi_{\text {tab }}^{2}$ & Keterangan \\
\hline Pree-test & 2.9648 & 7.81 & Terdistribusi normal \\
\hline Post-test & 4.655 & 7.81 & Terdistribusi normal \\
\hline \multicolumn{4}{r}{ Pada $\alpha=0.05$} \\
\end{tabular}

Sumber: Data Diolah (2017)

b. Pengujian Homogenitas Data varians terkecil (Sudjana, 1996). Hasil Varians

Pengujian homogenitas data menggunakan uji $F$ (Varians) yaitu membandingkan varians terbesar uji homogenitas pree-test dan Post-test kedua kelompok sampel penelitian dengan ditunjukkan pada Tabel 5berikut,

Tabel 5 Hasil Uji Homogenitas pree-test dan post-test

\begin{tabular}{cccc}
\hline Data Yang Di Uji & $\mathrm{F}_{\text {hit }}$ & $\mathrm{F}_{\text {tab }}$ & Keterangan \\
\hline Pree-test & 1.287 & 4.18 & Homogen \\
\hline Post-test & 1.12 & 4.18 & Homogen \\
\hline
\end{tabular}


Pada $\alpha=0.05$

Sumber: Data Diolah (2017)

\section{c. Pengujian Hipotesis}

\section{Uji Kesamaan Dua Rata-Rata} Pree-Test

Tabel 7 Hasil Uji Kesamaan Dua Rata Rata Hasil Pree-Test

\begin{tabular}{ccccccc}
\hline Kelas & Rata-Rata & Varians & $\mathrm{n}$ & $\mathrm{S}_{\text {gab }}$ & $\mathrm{T}_{\text {hit }}$ & $\mathrm{T}_{\text {tab }}$ \\
\hline Eksperimen & 31,99 & 188,2 & 30 & 12,93 & 1,142 & 2,001 \\
\hline Kontrol & 28,21 & 146,2 & 30 \\
\hline Kesimpulan & \multicolumn{7}{c}{ Tidak ada beda } \\
\hline
\end{tabular}

Sumber: Data Diolah (2017)

\section{Uji Kesamaan Dua Rata-Rata}

Post-Test

Hasil uji hipotesis dua rata-rata post-test kedua kelompok sampel

Tabel 8 Hasil Uji Kesamaan Dua Rata Rata Hasil Post-Test

\begin{tabular}{ccccccc}
\hline Kelas & Rata-Rata & Varians & $\mathrm{n}$ & $\mathrm{S}_{\mathrm{gab}}$ & $\mathrm{T}_{\text {hit }}$ & $\mathrm{T}_{\text {tab }}$ \\
\hline Eksperimen & 73,33 & 101,15 & 30 & 10.36 & 1,86 & 2,001 \\
\hline Kontrol & 67,77 & 113,68 & 30 \\
\hline Kesimpulan & \multicolumn{7}{c}{ Tidak ada beda } \\
\hline
\end{tabular}

Sumber: Data Diolah (2017)

\section{Efektivitas Berdasarkan nilai Normal Gain}

Pada hipotesis dua rata-rata gain ini untuk melihat apakah nilai rata-rata gain kelas eksperimen lebih signifikan dari rata-rata gain kelas kontrol pada

Tabel 9 Hasil Uji Kesamaan Dua Rata-Rata Gain

\begin{tabular}{ccccccc}
\hline Kelas & Rata-Rata & Varians & $\mathrm{n}$ & $\mathrm{S}_{\text {gab }}$ & $\mathrm{T}_{\text {hit }}$ & $\mathrm{T}_{\text {tab }}$ \\
\hline Eksperimen & 0,61 & 0,02 & 30 & 0,16 & 1,67 & 2,001 \\
\hline Kontrol & 0,54 & 0,03 & 30 & & & \\
\hline
\end{tabular}

Kesimpulan Tidak ada beda

Sumber: Data Diolah (2017)

\section{Pembahasan}

Berdasarkan hasil analisis deskriptif terhadap hasil belajar siswa sebelum pembelajaran (pree-test) pada materi pokok Fenomena Antroposfer dan Aspek Kependudukan sebagian materi Dinamika Penduduk sehingga terhindar dari efek tebakan dan kesimpulan yang bias. Hasil uji normalitas gain dapat dilihat pada tabel 9 berikut.
Hasil uji hipotesis dua rata-rata pree-test penelitian ditunjukkan pada Tabel 8 berikut: 8 
rata hasil belajar siswa sebesar 28.21. Jika memperhatikan rata-rata hasil belajar sebelum proses pembelajaran dilakukan dapat dikatakan bahwa ratarata hasil belajar kelas eksperimen dan kelas kontrol relatif sama atau perbedaannya sangat kecil. dari hasil pengujian hipotesis dilakukan, menunjukkan bahwa tidak terdapat perbedaan yang signifikan antara ratarata nilai pree-test siswa kelas eksperimen dengan rata-rata nilai preetets siswa kelas kontrol sebelum proses pembelajaran ditunjukkan dengan nilai $\mathrm{t}_{\text {tab } 1}<\mathrm{t}_{\text {hit }}(1.142<2.001)$. Hal ini diduga karena belum adanya perlakuan yaitu proses pembelajaran untuk materi pokok Fenomena Antroposfer dan Aspek Kependudukan baik pada kelas eksperimen maupun kelas kontrol.

Hasil belajar siswa setelah proses pembelajaran pada materi Fenomena Antroposfer dan Aspek Kependudukan mengalami peningkatan yang signifikan jika dibandingkan dengan hasil belajar siswa sebelum proses pembelajaran. Secara deskriptif hasil belajar kelas eksperimen setelah pembelajaran sebagian besar termasuk dalam kategori baik dan baik sekali, dan tidak ada siswa yang masuk dalam kategori gagal. Ini menunjukkan bahwa proses belajar yang dilakukan berhasil. Sedangkan hasil belajar siswa setelah pembelajaran pada kelas control sebagian besar termasuk dalam kategori baik dan ada siswa yang masuk dalam kategori kurang. Secara rata-rata hasil belajar siswa setelah pembelajaran kelas eksperimen lebih tinggi yaitu sebesar 73,33 jika dibandingkan dengan rata-rata hasil belajar siswa kelas kontrol yaitu sebesar 67,77. Dari hasil pengujian hipotesis diperoleh bahwa terdapat perbedaan antara rata-rata nilai post-test kelas eksperimen dengan rata-rata nilai posttest kelas kontrol. Dalam hal ini, ratarata post-test siswa kelas eksperimen lebih tinggi dari pada rata-rata post-test siswa kelas kontrol pada pokok bahasan Fenomena Antroposfer dan Aspek Kependudukan. perbedaan rata-rata kelas eksperimen dan kelas kontrol tidak signifikan. Hal ini ditunjukkan dengan nilai $\mathrm{t}_{\text {hit }}<\mathrm{t}_{\text {tab }}(1.86<2.001)$.pada taraf $\alpha$ $=0.05$. Berdasarkan uraian tersebut dapat kita lihat bahwa terdapat peningkatan yang tidak signifikan antara hasil belajar siswa pada kelas eksperimen dan kelas kontrol.Selain dikarenakan pemberian perlakuan (treatmen) yang berbeda dalam proses pembelajaran ternyata fakta dilapangan terkait faktor internal siswa pun berpengaruh pada pencapaian hasil dari treatmen yang diberikan.

Berdasarkan hasil analisis dekskriptif terlihat bahwa terdapat peningkatan rata-rata hasil belajar $(\mathrm{N}$ gain) siswa kelas eksperimen daripada rata-rata peningkatan hasil belajar siswa kelas kontrol tetapi peningkatannya tidak signifikan.Rata-rata $\mathrm{N}$-gain siswa kelas eksperimen adalah 0.61, sedangkan rata-rata $\mathrm{N}$-gain kelas kontrol adalah 0.54. Secara statistik inferensial menunjukkan adanya perbedaan antara rata-rata $\mathrm{N}$-gain siswa kelas eksperimen dengan rata-rata $\mathrm{N}$-gain siswa kelas kontrol pada taraf kepercayaan $95 \%(\alpha=$ $0.05)$ dengan derajat kebebasan $\mathrm{dk}=58$ yang menunjukkan bahwa $t_{h i t}<t_{t a b}$ $(1,67<2.001)$

Seluruh uraian diatas menunjukan bahwa pembelajaran geografi dengan menggunakan model pembelajaran Think Pair Share tidak dapat memberikan pengaruh yang berarti dan 
efektif dalam meningkatkan hasil belajar siswa kelas XI IPS SMAN 8 Kendari.

\section{KESIMPULAN}

Berdasarkan hasil analisis data terhadap hasil belajar Geografi baik pada kelas eksperimen maupun kelas kontrol yang diperoleh dalam penelitian ini, maka dapat ditarik kesimpulan sebagai berikut:

1. Ada perbedaan antara rata-rata pretest siswa kelas eksperimen dengan rata-rata pre-test siswa kelas kontrol tetapi tidak signifikan. Hal ini ditunjukkan oleh nilai $\mathrm{t}_{\text {tabe } 1}<\mathrm{t}_{\text {hitung }}$ $(1.142<2.001)$. pada $\alpha=0.05$.

2. Ada perbedaan antara rata-rata posttest siswa kelas eksperimen dengan rata-rata post-test siswa kelas kontrol tetapi tidak signifikan, yang ditunjukkan oleh nilai $t_{\text {hitung }}<\mathrm{t}_{\text {tabel }}$ $(1.86<2.001)$ pada $\alpha=0.05$.

3. Ada perbedaan antara $\mathrm{N}$-gain siswa kelas eksperimen dengan $\mathrm{N}$-gain siswa kelas kontrol tetapi tidak signifikan yang ditunjukkan oleh nilai $t_{\text {hitung }}<\mathrm{t}_{\text {tabel }}(1.67<2.001)$. pada $\alpha=0.05$.

\section{DAFTAR PUSTAKA}

Ibrahim, M. 2000. Pembelajaran Kooperatif. Surabaya: Program Pasca Sarjana Unesa.

Slavin. 1997. Cooperative Learning Theory, Reseach and Practise. The John Hopkins University Allyn and Bacon.

Sudjana. 2002. Metoda Statistika .Bandung: Tarsito.

Trianto. 2010. Mendesain Model Pembelajaran Inovatif Progresif, Jakarta: Kencana

Tuckman,B.W.1978. Conducting Educational Research. Harcourt
Brace Jovanovich Inc. Unitedstated OfAmerika.

Utoyo, Bambang. 2009. Geografi: Membuka Cakrawala Dunia untuk Kelas XI Sekolah Menengah Atas/Madrasah Aliyah. Jakarta : Pusat Perbukuan, Departemen Pendidikan Nasional. 
